\title{
Making do or moving forward: An assessment of our global food system
}

\author{
Book review by Linda M. Young * \\ Montana State University
}

\section{Review of Rethinking Food Systems: Structural Challenges, New Strategies and the Law, edited by Nadia C. S. Lambek, Priscilla Claeys, Adrienna Wong, and Lea Brilmayer. (2014). New York: Springer. Available in hardcover; 250 pages. Publisher's website: http://www.springer.com/environment/sustainable+ development/book/978-94-007-7777-4}

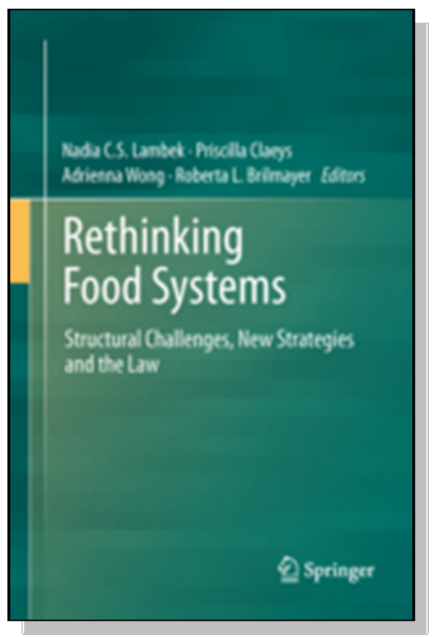

Published online January 20, 2015

Citation: Young, L. M. (2015). Making do or moving forward: An assessment of our global food system [Book review]. Journal of Agriculture, Food Systems, and Community Development, 5(2), 201-203. http://dx.doi.org/10.5304/jafscd.2015.052.003

Copyright (C) 2015 by New Leaf Associates, Inc.

$\mathrm{T}$ he rich and diverse perspectives of Lambek, Claeys, Wong, and Brilmayer in Rethinking Food Systems: Structural Challenges, New Strategies and the Law lend a great deal to their assessment of the extent to which our current system of institutions and law supports the achievement of a "just, equitable and sustainable" food system. The law here comprises a messy and complex mix of covenants, trade agreements, World Trade Organization (WTO) jurisprudence, and national laws. This book addresses the law, both as it exists and as it is being written in developing countries, while recognizing the institutional context and interests at play.

\footnotetext{
* Linda M. Young is an associate professor and head of the Department of Political Science at Montana State University. She is a political economist with training in agricultural economics, and does research on agricultural trade and trade negotiations, supply chains, agricultural policy and development, and food aid. She can be contacted at lmyoung@montana.edu
}

The fundamental question asked by the authors is whether the current institutional and legal structure governing global food systems can be rethought to serve communities, particularly the poor, rather than corporate interests and the elite. This question is the thread that unifies discussion of the "right to food" and disparate issues, such as how some states are incorporating this right into their constitutions, legal structures, and policies; the rejection of free trade for food sovereignty by an international social movement of peasants; the challenges presented by an increase in land grabs; and negotiation of competing concepts and treaties governing the intellectual property of farmers.

The book begins with a discussion of how an international constituency of peasants and small farmers, aligned through the international peasants' rights organization Via Campesina, contest both the intent and the process of the WTO's involvement in domestic agricultural policy. They reject the current practice of negotiating domestic agricultural policy at the international level in order to 
the intent and the process of the WTO's involvement in domestic agricultural policy. They reject the current practice of negotiating domestic agricultural policy at the international level in order to facilitate trade. Via Campesina argues that food sovereignty gives local and national constituencies a collective right to determine their agricultural and food policies. Claeys' chapter discusses the challenges faced by this social movement and the contradictions inherent in Via Campesina's framing of food sovereignty as a collective right, as rights emanate from the framework of liberalism-the same framework that gives rise to the capitalism and neoliberalism that underlie the WTO. Claeys explains how the food sovereignty movement is hampered by disagreement about whether these rights should be institutionalized from above, or nurtured from below with the design of challenging the entire institutional structure.

Some national governments are trying precariously to balance pressures for food sovereignty with their current involvement in the international trading regime. Araújo and Godek describe how the government of Nicaragua has passed the Law of Food and Nutritional Sovereignty and Security (SSAN) to promote Nicaragua's food selfsufficiency, support small and medium-sized farmers, and use a multistakeholder process for the development of agricultural policy at the local and national level. At the same time, the government of Nicaragua is ratifying regional free trade agreements that contradict the policies and processes of food sovereignty embraced by SSAN. This example epitomizes the tension faced by national governments caught between the demands of local constituencies for food sovereignty and by other, largely international, constituencies for free trade.

In sharp contradiction to the concept of food sovereignty is the increasing practice of "land grabbing," in which national governments and corporations lease large tracts of agricultural land for 50 to 100 years from developing countries. These agreements are usually regulated only through bilateral investment treaties, as they lie outside the scope of WTO and other multilateral disciplines. The authors of two chapters, Brilmayer and Moon, and Borras and Franco, argue that the root causes of rural poverty in lessor countries include insecure property rights, a democratic deficit in national policymaking, and the dominance of an exportoriented agricultural system controlled by transnational corporations. The authors concur that land grabs are more likely to deepen these problems than to ameliorate them, as long-term leases of large tracts of land result in the expulsion of small producers with insecure property rights and an increase in food insecurity for the poor.

However, the authors diverge in their discussion of possible solutions. Brilmayer and Moon assess the feasibility of using social labeling and import restrictions for the goods produced via land grabs as a way to reduce demand for them. They explore the fates of similar efforts that have been litigated under the Technical Barriers to Trade Agreement of the WTO, but their analysis yields little assurance that these are viable mechanisms to address the issue.

Borras and Franco assess whether codes of conduct proposed by multilateral organizations and institutes are adequate to address the consequences of land grabs. They conclude that such codes of conduct will legitimize these land grabs without recognizing and addressing the underlying conditions causing rural poverty. Given that the current institutional structure has nurtured an export-oriented agricultural system controlled by transnational corporations, lack of acknowledgment that this structure itself is to blame for rural poverty in these countries is not surprising, nor is it surprising that the proposed codes of conduct are unlikely to help ameliorate the consequences of land grabs.

The book has a rich discussion on the right to food and its ramifications for citizens, national governments and international institutions, and law. Rae examines the how stakeholders, government, and the legislature in Uganda are tackling interpretation of their 1995 constitution that recognizes the right to food. Rae's discussion highlights the challenge of clarifying the state's role in "respecting, protecting and fulfilling" the right to food. Rae attributes the process involved as contributing to democratization in Uganda, as local stakeholders play a pivotal role in defining the right to food, despite the undue influence of international donors. Rae distinguishes between "the right to food" and 
the "right to be fed," as the latter implies a substantial resource obligation on the part of the government. Rae does not address this reader's concern about the opportunity cost of devoting so many resources to the creation of rights by countries that do not have the institutional structure needed to interpret and deliver them.

Lambek clarifies that the right to food encompasses much more than the obligation for the state to feed the hungry. It also requires that "the state and third parties must not hinder the ability of individuals to meet their own food needs" (p. 101). Gonzalez explains the implication: "As such, the state is obligated to ensure that agricultural policies do not deprive farmers of their livelihoods. The state must also protect the right to food by taking measures to prevent third parties from depriving people of the means to either grow food or purchase food" (p. 168). From this starting point, Lambek recommends actions to support local communities and agricultural smallholders, including a reduction of agricultural subsidies in rich countries; use of WTO exceptions to enact policies supportive of smallholders; and disciplines on transnational corporations for anticompetitive practices. Lambek and Gonzalez (in separate chapters) each provide a rich interpretation of how international covenants form the legal basis for a right to food, and possible ramifications for agricultural policy at both the domestic and international levels.

Lambek et al. provide a detailed analysis of the tensions inherent in our current institutional and legal systems for agriculture and food. There is tension evident between the rights of producers and companies over intellectual property rights; between the rights of sovereign nations to lease land and the rights and needs of their smallholders; and between the role of the local communities and international institutions in developing agricultural policy. Underlying these tensions are fundamental challenges to our current system.

Claeys and Lambek question whether a "just, equitable and sustainable" food system can be achieved with our current institutions, and the nine chapters in the book provide a wealth of analysis on pivotal issues. However, Claeys and Lambek do not use the extensive analysis in the book to systematically answer the question they pose.

Several authors propose using the flexibility provided in current agreements to better serve local communities and small producers and discuss a host of suggested policies; however, the book does not articulate the question of whether the political will (Raile, Raile \& Post, 2014) to do so exists. Lambek et al. do present an aspirational view of the need to restructure our food system and the concepts, such as the right to food and food sovereignty, that might underlie it. Further work on the public will that is needed to achieve these aspirations would be a worthy successor for their book.

\section{Reference}

Raile, E. D., Raile, A. N. W., Salmon, C. T., \& Post, L. A. (2014). Defining public will. Politics and Polity, 42(1), 103-130. http://dx.doi.org/10.1111/polp.12063 